\title{
PROFESIONALITAS KEPALA SEKOLAH: Analisis Antara Idealita dan Realita
}

\author{
Oleh: Sitti Mania*
}

\begin{abstract}
A head master as a top leader of a school is responsible for a hard job and determines the future of the school. The head master should have three important skills; they are technical competence related to specific skills for running operational activities of as a head master. The second is interpersonal competence; this is a skill to work with others and to motivate teachers and other subordinates. Finally, conceptual competence; this is about the head master's ability to produce concept, to analyse and solve problems of schools. Despite this, a number of headmasters cannot run their daily activities as it should be due to a number of factors. This paper discusses a number of ways to overcome such issue.
\end{abstract}

KEYWORDS: Head master, profesionalism, competence.

SALAH satu program yang dapat menyiapkan arah perkembangan masyarakat Indonesia di masa depan adalah pendidikan. Pendidikan dalam konsep pengembangan masyarakat merupakan dinamisasi dalam pengembangan manusia yang beradab. Pendidikan tidak hanya terbatas berperan pada pengalihan ilmu pengetahuan (transfer of knowledge) saja, namun dalam Undang-undang No: 20 tahun 2003 tentang Sistem Pendidikan Nasional disebutkan bahwa pendidikan memiliki fungsi mengembangkan kemampuan dan membentuk watak serta peradaban bangsa yang bermartabat dalam rangka mencerdaskan kehidupan bangsa, bertujuan untuk berkembangnya potensi peserta didik agar menjadi manusia yang beriman dan bertakwa kepada Tuhan Yang Maha Esa, berakhlak mulia, sehat, berilmu, cakap, kreatif, mandiri, dan menjadi warga negara yang demokratis serta bertanggung jawab. Dari fungsi dan tujuan pendidikan ini diharapkan manusia Indonesia adalah manusia yang berimbang antara segi kognitif, afektif, dan psikomotor. Dalam pencapaian tujuan pendidikan nasional, dunia pendidikan kita secara nasional dihadapkan pada salah

*Kandidat Doktor Evaluasi Pendidikan pada Program Pascasarjana Universitas Negeri Jakarta ini adalah Dosen Tetap Fakultas Tarbiyah dan Keguruan UIN Alauddin Makassar. 
satu masalah besar yakni peningkatan mutu dan relevansi pendidikan. Masalah ini menjadi fokus yang paling penting dalam pembangunan pendidikan nasional. Pembangunan pendidikan menjadi tolok ukur kemajuan SDM suatu Negara. Rendahnya kualitas SDM akan menjadi batu sandungan dalam era globalisasi, karena era globalisasi merupakan era persaingan kualitas. Jika bangsa Indonesia ingin berkiprah dalam dunia global maka langkah pertama yang harus dilaksanakan adalah menata SDM, baik dari aspek intelektual, emosional, spiritual, kreativitas, moral maupun tanggung jawabnya. Penataan ini perlu diupayakan secara bertahap dan berkesinambungan melalui sistem pendidikan yang berkualitas.Rendahnya mutu dan relevansi pendidikan tersebut dipengaruhi oleh sejumlah faktor. Di antara faktor terpenting adalah terkait dengan kinerja kepala sekolah dalam mengelola sekolah sebagai satu satuan pendidikan yang menyelenggarakan proses pembelajaran kepada peserta didik.

Kepala sekolah merupakan salah satu komponen pendidikan yang paling berperan dalam meningkatkan kualitas pendidikan. Sebagaimana dikemukakan dalam Pasal 12 ayat 1 PP 28 tahun 1990 bahwa: "Kepala sekolah bertanggungjawab atas penyelenggaraan kegiatan pendidikan, administrasi sekolah, pembinaan tenaga kependidikan lainnya, dan pendayagunaan serta pemeliharaan sarana dan prasarana".

Namun kenyataan di lapangan masih banyak kepala sekolah yang tidak menjalankan tugas dan fungsinya sebagai pemimpin pendidikan yang diharapkan. Kenyataan ini disebabkan oleh beberapa hal, bisa karena dalam proses pengangkatannya tidak ada transparansi, rendahnya mental kepala sekolah yang ditandai dengan kurangnya motivasi dan semangat serta kurangnya disiplin dalam melakukan tugas, dan seringnya datang terlambat serta banyak faktor penghambat lainnya, yang pada akhirnya berpengaruh terhadap rendahnya produktivitas kerja kepala sekolah yang bersangkutan dan berimplikasi juga pada mutu (input, proses, dan output). Kenyataan di lapangan seperti yang diutarakan di atas, yang akan dibahas dalam tulisan ini.

\section{STANDAR KOMPETENSI KEPEMIMPINAN KEPALA SEKOLAH}

Pimpinan yang kompeten adalah yang memiliki pengetahuan, sikap, dan keterampilan untuk melakukan sesuatu. Ada tiga kompetensi yang harus dimiliki kepala sekolah yaitu: 1) kompetensi teknis (technical competency) berkenaan dengan pengetahuan khusus yang diperlukan untuk melaksanakan tugas pokok dan fungsi sebagai Kepala Sekolah, 2) kompetensi hubungan antar pribadi (interpersonal competency) yang berkenaan 
dengan kemampuan kepala sekolah dalam bekerjasama dengan orang lain dan memotivasi mereka agar bersungguh-sungguh dalam bekerja, 3) kompetensi konseptual (conceptual competency) berkenaan dengan keluasan wawasan dan konsep seorang kepala sekolah yang diperlukan dalam menganalisis dan memecahkan masalah rumit berkenaan dengan pengelolaan sekolah. ${ }^{1}$

Sejalan dengan pendapat di atas, Sagala mengemukakan beberapa kompetensi yang mesti dimiliki oleh kepala sekolah: a) kompetensi kepribadian. Kompetensi kepribadian pertama, memiliki integritas kepribadian yang kuat sebagai pemimpin yaitu: 1) selalu konsisten dalam berpikir, bersikap, berucap, dan berbuat dalam setiap melaksanakan suatu tugas pokok dan fungsi, 2) memiliki komitmen, loyalitas, dan etos kerja yang tinggi dalam setiap melaksanakan suatu tugas pokok dan fungsi, 3) tegas dalam mengambil sikap dan tindakan sehubungan dengan pelaksanaan suatu tugas dan fungsi, dan 4) disiplin dalam melaksanakan suatu tugas dan fungsi. Kedua, memiliki keinginan yang kuat dalam pengembangan diri sebagai kepala sekolah yaitu: 1) memiliki rasa keingintahuan yang tinggi terhadap kebijakan, teori, praktik baru sehubungan dengan pelaksanaan suatu tugas pokok dan fungsinya, dan 2) mampu secara mandiri mengembangkan diri sebagai upaya pemenuhan rasa keingintahuannya terhadap kebijakan, teori, praktik baru sehubungan dengan pelaksanaan suatu tugas pokok dan fungsi. Ketiga, bersikap terbuka dalam melaksanakan tugas pokok dan fungsi yaitu: 1) kecenderungan untuk selalu menginformasikan secara transparan dan proporsional kepada orang lain atas segala rencana, proses pelaksanaan, dan keefektifan, kelebihan dan kekurangan pelaksanaan suatu tugas pokok dan fungsi, dan 2) terbuka atas saran dan kritik yang disampaikan atasan, teman sejawat, bawahan, dan pihak lain atas pelaksanaan suatu tugas pokok dan fungsi. Keempat, mampu mengendalikan diri dalam menghadapi masalah dalam pekerjaan sebagai kepala sekolah, yaitu: memiliki stabilitas emosi dalam setiap menghadapi masalah sehubungan dengan pelaksanaan suatu tugas pokok dan fungsi, 2) teliti, cermat, dan hati-hati dalam melaksanakan suatu tugas pokok dan fungsi, dan 3) tidak mudah putus asa dalam menghadapi segala bentuk kegagalan sehubungan dengan pelaksanaan suatu tugas pokok dan fungsi. Kelima, memiliki bakat dan minat jabatan sebagai pemimpin pendidikan yaitu: 1) memiliki minat yang kuat memangku jabatan untuk menjadi kepala yang efektif, 2) memiliki jiwa kepemimpinan yang proaktif, dinamis sesuai dengan kebutuhan sekolah. 


\section{Kompetensi Manajerial}

Kompetensi ini meliputi pertama, kemampuan menyusun perencanaan sekolah untuk berbagai tingkatan, yaitu; 1) menguasai teori perencanaan dan seluruh kebijakan pendidikan nasional sebagai landasan dalam perencanaan sekolah, 2) mampu menyusun rencana strategis pengembangan sekolah berlandaskan kebijakan pendidikan nasional, 3) mampu menyusun rencana operasional pengembangan sekolah, 4) mampu menyusun rencana tahunan pengembangan sekolah, 5) mampu menyusun rencana anggaran belanja sekolah berdasarkan rencana kerja tahunan, 6) mampu menyusun perencanaan program kegiatan, 7) mampu menyusun proposal kegiatan. Kedua, mampu mengembangkan organisasi sekolah sesuai kebutuhan, yaitu: 1) menguasai teori dan kebijakan pendidikan nasional dalam pengorganisasian kelembagaan sekolah, 2) mampu mengembangkan struktur organisasi formal kelembagaan sekolah sesuai kebutuhan, 3) mampu mengembangkan deskripsi tugas pokok dan fungsi setiap unit kerja, 4) menempatkan personalia yang sesuai dengan kebutuhan, 5) mampu mengembangkan standar operasional prosedur pelaksanaan tugas pokok dan fungsi setiap unit kerja, 6) mampu melakukan penem-patan pendidik dan tenaga kependidikan sesuai dengan prinsip-prinsip yang tepat, 7) mampu mengembangkan aneka ragam organisasi informal sekolah. Ketiga, mampu memimpin guru dan staf dalam rangka pendayagunaan SDM secara optimal, yaitu 1) mampu mengkomunikasikan visi, misi, tujuan, sasaran, dan program strategis sekolah kepada seluruh guru dan staf, 2) mampu mengkoordinasi guru dan staf dalam merealisasikan seluruh rencana untuk menggapai visi dan sasaran sekolah, 3) mampu mengarahkan dan memotivasi guru dan staf, 4) mampu membangun kerjasama tim dalam memajukan sekolah, 5) mampu melengkapi guru dan staf dengan keterampilan yang sesuai dengan tugas pokok dan fungsinya serta untuk kemajuan sekolah, 6) mampu memimpin rapat yang aspiratif dan persuasif dengan guru-guru, staf, dan komite sekolah, 7) mampu mengambil keputusan dengan penuh pertimbangan, dan 8) mampu menerapkan manajemen konflik. Keempat, mampu mengelola guru dan staf dalam rangka pendayagunaan SDM secara optimal yaitu: 1) mampu merencanakan kebutuhan guru dan staf berdasarkan rencana pengembangan sekolah, 2) mampu melaksanakan rekrutmen dan seleksi guru dan staf sesuai dengan kewenangan sekolah, 3) mampu mengelola kegiatan pembinaan dan pengembangan professional guru dan staf, 4) mampu mengelola pemberian kesejahteraan kepada guru dan staf. Kelima, mampu mengelola sarana dan prasarana sekolah yaitu, 1) mampu merencanakan kebutuhan fasilitas sekolah 
sesuai rencana pengembangan sekolah, 2) mampu mengelola pengadaan fasilitas, 3) mampu mengelola pemeliharaan fasilitas, 4) mampu mengelola kegiatan inventaris sarana dan prasarana sekolah, 5) mampu mengelola penghapusan barang inventaris sekolah. Keenam, mampu mengelola hubungan sekolah-masyarakat dalam rangka pencarian dukungan ide, sumber belajar, dan pembiayaan sekolah. Ketujuh, mampu mengelola penerimaan peserta didik, penempatan peserta didik, dan pengembangan kapasitas peserta didik. Kedelapan, mengelola pengembangan kurikulum dan kegiatan belajar mengajar sesuai arah dan tujuan pendidikan nasional. Kesembilan, mampu mengelola keuangan sekolah sesuai dengan prinsip pengelolaan yang akuntabel, transparan, dan efisien. Kesepuluh, mampu mengelola ketatausahaan sekolah dalam mendukung kegiatan-kegiatan sekolah. Kesebelas, mengelola unit layanan khusus sekolah dalam mendukung kegiatan pembelajaran dan kegiatan peserta didik di sekolah. Kedua belas, mampu menerapkan prinsip-prinsip kewirausahaan dalam menciptakan inovasi yang berguna bagi pengembangan sekolah. Ketiga belas, mampu menciptakan budaya dan iklim kerja yang kondusif bagi pembelajaran peserta didik. Keempat belas, terampil dalam memanfaatkan kemajuan teknologi informasi bagi peningkatan pembelajaran dan manajemen sekolah dan mampu mengelola sistem informasi sekolah dalam mendu-kung penyusunan program dan pengambilan keputusan. Kelima belas, mampu dan terampil mengelola kegiatan produksi/jasa sebagai sumber belajar siswa dan untuk mendukung sumber pembiayaan sekolah.

\section{Kompetensi Supervisi}

Kepala sekolah harus mempunyai kemampuan mensupervisi dan mengaudit kinerja guru dan personal lainnya. Kemampuan dalam hal ini meliputi: pertama, mampu melakukan supervisi sesuai prosedur dan teknik-teknik yang tepat. Kedua, mampu melakukan monitoring, evaluasi dan pelaporan program pendidikan sesuai dengan prosedur yang tepat.

\section{Kompetensi Sosial}

Kepala sekolah harus mampu beradaptasi dengan lingkungan sosial budaya di mana ia berada dan menggali nilai-nilai yang terkandung di dalamnya. Hal ini mendorong kepala sekolah harus memiliki kemampuan sosial baik pada lingkungan internal sekolah, lingkungan masyarakat secara umum. Kemampuan ini meliputi: pertama, terampil bekerja sama dengan orang lain berdasarkan prinsip yang saling menguntungkan dan memberi manfaat bagi sekolah. Kedua, mampu berpartisipasi dalam kegiatan sosial kemasyarakatan. Ketiga, memiliki kepekaan sosial terhadap orang atau kelompok lain. ${ }^{2}$ 
Sejauh mana kepala sekolah dapat mewujudkan peran-peran di atas, secara langsung maupun tidak langsung dapat memberikan kontribusi terhadap peningkatan kompetensi guru, yang pada gilirannya dapat membawa efek terhadap peningkatan mutu pendidikan di sekolah.

\section{FAKTA DI LAPANGAN}

\section{Rendahnya Mutu Kepala Sekolah}

Sagala dalam bukunya mengatakan bahwa banyak hasil penelitian yang menunjukkan bahwa tidak sedikit kepala sekolah yang belum mampu mengikutsertakan guru dan komite sekolah dalam menyusun rencana strategis (renstra) sekolah. Di antara kepala sekolah itu ada yang belum memahami bagaimana cara yang benar merumuskan visi dan misi sekolah. Mereka tidak mampu melakukan analisis kekuatan, kelemahan, peluang, dan tantangan sekolahnya masing-masing, cenderung menunggu apa yang dikatakan para pejabat dinas pendidikan. Kepala sekolah seperti ini terbiasa menerima, menelaah, dan mengamalkan petunjuk teknis, dan tidak terbiasa melakukan pengelolaan kurikulum, kepegawaian, sarana dan prasarana, keuangan, dan hubungan sekolah dengan masyarakat dengan cara yang demokratis. Berangkat dari fenomena tersebut, Kelompok Kerja Kepala Sekolah Direktorat Tenaga Kependidikan menyusun konsep standar kualifikasi dan kompetensi kepala sekolah. ${ }^{3}$

Pernyataan di atas dipertegas oleh Direktur Tenaga Kependidikan Depdiknas Surya Dharma, bahwa kebanyakan kepala sekolah di Indonesia lemah dalam kompetensi manajerial dan supervisi, proses rekrutmen yang kurang baik ditengarai menjadi penyebabnya. ${ }^{4}$ Lebih jauh, dia mengatakan bahwa berdasarkan Permendiknas No 13 Tahun 2007 mengenai standar kompetensi bagi kepala sekolah, ada lima aspek kompetensi yang harus ada dalam diri seorang kepala sekolah yakni kompetensi kepribadian yang menyangkut integritas dan kejujuran; kompetensi sosial yang mencakup hubungan antarmanusia dan hubungan baik dengan sesama; kompetensi manajerial yang terkait kemampuan kepala sekolah mengelola sekolah dan sumber daya yang ada di sekolah. Selanjutnya kompetensi supervisi yang menuntut kepala sekolah harus dapat membimbing guru-guru serta anak didiknya dan menggunakan sumber-sumber daya yang ada di sekolah. Terakhir, kompetensi kewirausahaan di mana seorang kepala sekolah harus mampu berwirausaha namun bukan untuk mencari keuntungan, memiliki jiwa kreatif, inisiatif dan berani mengambil resiko demi pengembangan sekolahnya. 


\section{Rendahnya Penghargaan terhadap Guru dan Kepala Sekolah}

Dalam sebuah media diberitakan bahwa ratusan guru SMP, SMA, dan SMK beserta kepala sekolah negeri Kota Tegal mendatangi Kantor Walikota Tegal. Mereka meminta kenaikan tambahan penghasilan dan menolak diskriminasi terhadap posisi mereka sebagai tenaga fungsional. Tuntutan tersebut disampaikan terkait dengan keluarnya Peraturan Walikota Tegal Nomor 17 Tahun 2007 tentang Tambahan Penghasilan Pegawai di Lingkungan Pemerintahan Kota Tegal. Tambahan penghasilan diberikan setiap bulan kepada PNS dan pegawai non PNS di lingkungan Pemkot Tegal. Besarnya tambahan penghasilan disesuaikan dengan beban kerja masing-masing jabatan.

Hal itu dilakukan oleh para guru dan kepala sekolah karena merasa mendapat perlakuan diskriminasi dalam hal pemberian tambahan penghasilan. Sesuai peraturan walikota, tambahan penghasilan yang diberikan kepada guru dan kepala SMP, SMA, dan SMK negeri sebesar Rp 41.000 per bulan. Besarnya tambahan penghasilan tersebut berada di bawah tambahan penghasilan bagi tenaga harian lepas atau THL dan tenaga kontrak, sebesar Rp 116.000 per bulan. Padahal tambahan penghasilan tersebut diberikan sesuai dengan beban kerja masing-masing. Dengan kondisi tersebut, para guru dan kepala sekolah merasa diperlakukan diskriminatif. Beban kerja mereka dinilai ringan, sehingga tambahan penghasilan yang diberikan rendah. Padahal tugas guru sangat berat, sebab ia bertanggung jawab membentuk karakter masyarakat melalui pendidikan. Seharusnya, guru dan kepala sekolah SMP, SMA, dan SMK dimasukkan dalam golongan PNS yang menduduki jabatan fungsional. Sesuai peraturan walikota tersebut, PNS yang menduduki jabatan fungsional mendapatkan tambahan penghasilan sebesar Rp 166.000 per bulan. Oleh karena itu, para guru dan kepala sekolah meminta agar Pemkot Tegal menghilangkan diskriminasi tersebut. ${ }^{5}$

\section{Tuntutan Profesionalisme Vs. Tuntutan Pemenuhan Kebutuhan}

Salah satu program 100 hari Mendiknas, adalah mencanangkan guru sebagai profesi seperti halnya wartawan, dokter, dan profesi lainnya. "Sebagai suatu profesi, nantinya akan ada kode etik yang harus dipenuhi para guru. Jika melanggar, akan ada konsekuensi. Guru juga terdorong menjalankan tugasnya dengan baik, dan kode etik juga akan melindungi profesi guru," kata pengamat pendidikan UPI Bandung, Prof. Said Hamid Hasan. ${ }^{6}$ Memosisikan guru sebagai profesi, suatu hal yang mendesak diberlakukan di Indonesia. Pasalnya, menempatkan guru seperti itu akan memperbaiki nasib para guru yang selama ini sering termarginalkan. Guru 
juga akan menjadi lebih bertanggung jawab dalam menjalankan tugasnya. Masalahnya, bagaimana guru mengantisipasi tuntutan seperti itu, sehingga dapat mengembangkan profesionalismenya. ${ }^{7}$

Malcon Allerd mengatakan, sifat dan kepribadian guru dan kepala sekolah yang amat penting artinya bagi proses pembelajaran adalah adaptabilitas, antusiasme, kepercayaan diri, ketelitian, empati, dan kerjasama yang baik. Guru dan kepala sekolah juga dituntut untuk mereformasi pendidikan, bagaimana memanfaatkan semaksimal mungkin sumber-sumber belajar di luar sekolah, perombakan struktural hubungan antara guru dan murid, seperti layaknya hubungan pertemanan, penggunaan teknologi modern dan penguasaan iptek, kerja sama dengan teman sejawat antar-sekolah, serta kerja sama dengan komunitas lingkungannya. ${ }^{8}$

Gambaran itu menunjukkan, betapa tingginya tuntutan profesionalisme seorang guru tidak terkecuali kepala sekolah. Bisa dipastikan, dengan tingkat penghasilan yang rendah, rasanya sulit mengikuti tuntutan itu.

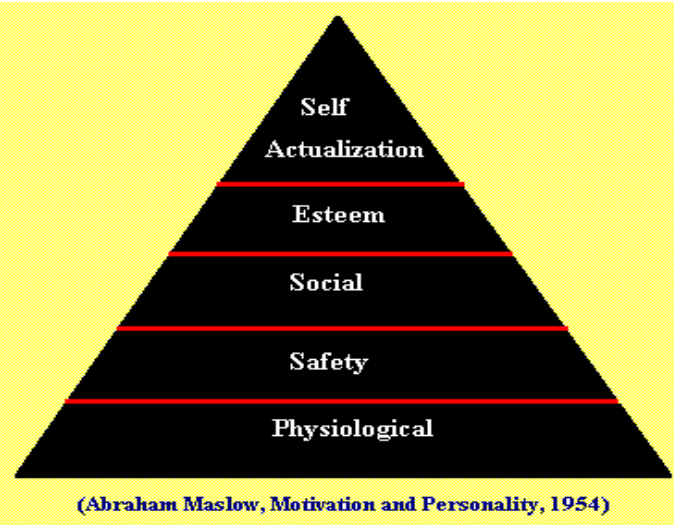

Kalau kita percaya pada 'Abraham Maslow' kebutuhan utama seseorang manusia survival biologis, maka seorang guru juga akan mengutamakan keberlangsungan hidup ketimbang memikirkan profesionalismenya. Ini menyebabkan kontradiksi antara idealita dengan realita seorang guru.

Ada beberapa faktor yang menyebabkan guru dan kepala sekolah kurang profesional dalam memangku jabatannya. Pertama, faktor internal biologis. Guru adalah manusia yang juga butuh kesehatan dan nutrisi seimbang melalui pola makan yang sehat agar bisa produktif. Kedua, faktor internal psikologis. Di samping punya tanggung jawab terhadap anak didik dan lembaga pendidikan, guru juga punya tanggung jawab terhadap keluarga (anak, suami/istri). Dengan penghasilan minim, ia akan meng- 
alami ketidakpastian kesejahteraan hidup diri dan keluarganya. Sehingga satu per satu akan muncul kebutuhan atau dorongan lain. Keadaan munculnya dua kebutuhan atau lebih saat bersamaan, akan menimbulkan konflik. Kurt Lewin (1890-1947) membedakan tiga macam konflik. Konflik yang dialami para guru adalah konflik approach, yakni jika dua kebutuhan atau lebih muncul secara bersamaan dan keduanya mempunyai nilai positif bagi individu. Jika muncul kebutuhan atau dorongan untuk bertindak tapi tidak dapat terpenuhi atau terhambat, akan menyebabkan frustrasi atau depresi. Gangguan frustrasi atau depresi secara fisik memang tidak tampak, namun siksaan bagi para pengidapnya sangat berat. Setiap detik penderita akan disesaki oleh kekhawatiran, ketakutan dan kengerian. Jadi bagaimana mungkin seorang guru harus berkarya, kalau setiap hari frustrasi atau depresi? ${ }^{9}$

Ketiga, faktor eksternal psikologi. Gaji yang minim, penunjang profesionalitas juga minim. Kalau gaji minim tapi tanggung jawab berat, guru akan merasa tidak dihargai.

\section{Rekrutmen}

Hal yang tidak kalah penting, yang perlu diperhatikan adalah proses rekrutmen guru dan kepala sekolah. Proses rekrutmen guru dan kepala sekolah tidak sekadar mengisi kekosongan, tapi juga bertujuan untuk meningkatkan mutu pendidikan. Sebab meski maraknya teknologi informasi mampu mengadakan sumber ajar yang besar, guru tetap memiliki peran strategis dalam dunia pendidikan. Sebagaimana pernah disampaikan Ketua Umum PGRI, Muhammad Surya, pengembangan profesionalisme guru dan kepala sekolah seharusnya sudah dimulai sejak masa perekrutan. Selain itu perlu didukung fasilitas yang memadai. Perbaikan kesejahteraan guru dan kepala sekolah merupakan agenda penting yang tidak bisa ditinggalkan.

Khusus rekrutmen kepala sekolah, ada fenomena lain yang tidak boleh luput dari pengamatan yaitu fenomena pentingnya "Vitamin D" sebagai data pendukung utama. Fenomena ini sudah jelas akan mengaburkan fungsi utama seorang kepala sekolah sebagai School Master dan Head Teacher. Sebagai School Master, kepala sekolah diharapkan mampu merencanakan, mengorganisasikan dan mengerahkan segala sumber daya yang ada di lingkungan sekolah yang dibinanya bagi kelangsungan kegiatan belajar mengajar yang efektif dan efisien. Sedangkan sebagai Head Teacher, seorang kepala sekolah disyaratkan mampu menguasai manajerial, merancang, melaksanakan dan mengevaluasi kegiatan belajar mengajar. Selebihnya diharapkan mampu menampung keinginan masyarakat yang berkaitan dalam peningkatan mutu sekolah yang dipimpinnya. 
Ditinjau dari satu sudut fungsi saja, sudah terlihat betapa ada ketimpangan yang sangat signifikan sekali. Seorang kepala sekolah yang diangkat dengan berbasis dukungan "Vitamin D" akan kesulitan memerankan fungsinya sebagai school master dan head teacher. Hal ini lantaran, kepala sekolah yang bersangkutan hari-harinya akan selalu diliputi pemikiran bagaimana mengembalikan "Vitamin D" yang pernah dikeluarkan, bukan berpikir bagaimana meningkatkan dan mengembangkan potensi dan sumber daya sekolah yang dikelolanya.

Kondisi dilematis inilah, akhirnya melahirkan bisnis pendidikan dengan objek peserta didik yang harus membeli berbagai "produk" pelajaran di luar batas. Sebagai contoh, sekolah-sekolah yang berada di perkotaan (SD misalnya), sering kali mewajibkan peserta didiknya untuk membeli berbagai lembar kegiatan siswa (LKS) yang sebetulnya bukan bermaksud menambah wawasan anak, namun semata-mata untuk "keuntungan" sekolah. Lebih parah lagi, apabila beberapa LKS yang dibeli tidak dibahas secara tuntas namun hanya dikerjakan anak sementara materi yang ada belum sempat diterangkan oleh pendidik. Sedang pendidik sendiri merasa tidak ada beban sama sekali, lantaran memegang kunci jawaban dari LKS tersebut. 10

\section{Masa Jabatan}

Dalam dunia pendidikan TK, SD, SLTP, SMU, jabatan Kepala Sekolah boleh dikatakan seumur hidup. Mereka tidak akan kembali bertugas menjadi guru, walau yang bersangkutan sebetulnya sudah tidak mampu melakukan aktivitasnya secara total. Pemungsian jabatan kepala sekolah secara abadi akan berdampak pada penurunan kinerja dan proses transaksi pendidikan menjadi statis. Kepala sekolah yang sudah memasuki usia tua, kebanyakan tidak cukup handal dalam mengelola lembaga pendidikan. Hal ini bisa dilihat dari minimnya aktivitas, prestasi dan etos kerja dari lingkup pendidikan yang dipimpinnya. Apalagi kalau jabatan Kepala sekolah yang disandangnya didapat layaknya mengkarbit pisang yang masih muda, tentunya kehancuran dan malapetaka lambat laun akan menghiasi dunia pendidikan di Indonesia.

Ironisnya, ketika muncul fenomena Kepala Sekolah yang cenderung "diam dalam kursinya", produk hukum pendidikan Indonesia tidak mampu untuk memberi pelajaran tegas. Hal ini lantaran, seorang Kepala Sekolah berasumsi bahwa ia tidak mungkin dicopot dari jabatannya. Fenomena ini kerap kali terjadi, bukan saja dunia pendidikan yang termasuk kawasan pedesaan/pinggiran kota, namun juga daerah perkotaan. Kepala sekolah di daerah pedesaan/pinggiran kota biasanya hanya duduk sambil me- 
nunggu jam pulang berdentang. Kadang kala bisa berangkat telat dan pulang lebih cepat lantaran jauh dari pengawasan. Berbeda bila kepala sekolah berada di perkotaan, pada mulanya aktif dalam mengintegrasikan berbagai komponen demi kemajuan sekolah yang dipimpinannya. Namun lambat laun lantaran banyak celah yang bernuansa uang maka terjadi pergeseran pemikiran. Mengemban tugas bukan lagi berpikir untuk kemajuan sekolah akan tetapi berpikir bagaimana mendapat peluang bisnis dengan para penerbit Lembar Kegiatan Siswa (LKS) atau perusahaan lain yang dapat memberi keuntungan material.

Pergeseran tugas itulah sebetulnya potret kepala sekolah di dunia pendidikan Indonesia. Walau tidak semua kepala sekolah menunjukkan adanya pergeseran tugas dan tanggung jawab, namun fakta empiris kebanyakan para kepala sekolah khususnya SD menunjukan kecenderungan untuk berspekulasi bisnis di bidang yang seharusnya tidak layak dijadikan ajang bisnis. ${ }^{11}$

\section{SOLUSI}

Di atas sudah dikemukakan beberapa fakta yang menunjukkan rendahnya mutu kepala sekolah yang menyebabkan kepala sekolah yang bersangkutan kurang professional dalam menjalankan tugasnya. Dalam rangka peningkatan mutu kepala sekolah sebaiknya diarahkan kepada pembentukan kepala sekolah yang efektif, dan peningkatannya sebaiknya diawali pengembangan standar kompetensi kepala sekolah yang berdasarkan tugas pokok dan fungsinya. ${ }^{12}$ Pertanyaan yang muncul kemudian adalah bagaimanakah karakteristik kepala sekolah yang efektif?. Untuk menjawab pertanyaan ini, Sagala mengutip hasil penelitian yang dilakukan Tiong, bahwa kepala sekolah yang efektif adalah; 1) adil dan tegas dalam mengambil keputusan, 2) membagi tugas secara adil kepada guru, 3) menghargai partisipasi staf, 4) memahami perasaan guru, 5) memiliki visi dan berupaya melakukan perubahan, 6) terampil dan tertib, 7) berkemampuan dan efisien, 8) memiliki dedikasi dan rajin, 9) tulus dan ikhlas, 10) percaya diri.

Tawaran lain adalah: 1). Pembinaan kemampuan profesional kepala sekolah. Terdapat beberapa wadah yang telah dikembangkan dalam pembinaan kemampuan profesional kepala sekolah diantaranya musyawarah kepala sekolah (MKS) , kelompok kerja kepala sekolah (KKKS), pusat kegiatan kepala sekolah (PKKS). Disamping itu peningkatan dapat dilakukan melalui pendidikan, dengan program sarjana atau pasca sarjana bagi para kepala sekolah sesuai dengan bidang keahliannya, sehingga tidak terlepas 
dari koridor disiplin ilmu masing-masing. 2). Revitalisasi MGMP dan MKS di sekolah. Melalui MGMP dan MKS dapat dipikirkan bagaimana menyiasati kurikulum yang padat dan mencari alternatif pembelajaran yang tepat serta menemukan berbagai variasi metoda dan variasi media untuk meningkatkan kualitas pembelajaran. Dengan mengefektifkan MGMP dan MKS semua kesulitan dan permasalahan yang dihadapi oleh guru dan kepala sekolah dalam kegiatan pendidikan dapat dipecahkan, dan diharapkan dapat meningkatkan mutu pendidikan di sekolah. 3). Peningkatan disiplin. Untuk melahirkan kepala sekolah profesional dalam paradigma baru manajemen pendidikan di sekolah diperlukan adanya peningkatan disiplin untuk menciptakan iklim sekolah yang lebih kondusif dan dapat memotivasi kerja, serta menciptakan budaya kerja dan budaya disiplin para tenaga kependidikan dalam melakukan tugasnya di sekolah. 4). Pembentukan kelompok diskusi profesi. Kelompok diskusi profesi dapat dibentuk untuk mengatasi tenaga kependidikan yang kurang semangat dalam melakukan tugas-tugas kependidikan di sekolah yang melibatkan pengawas sekolah, komite sekolah atau orang lain yang ahli dalam memecahkan masalah yang dihadapi kepala sekolah dan tenaga kependidikan. 5). Peningkatan layanan perpustakaan dan penambahan koleksi. Salah satu sarana peningkatan profesionalisme kepala sekolah adalah tersedianya buku yang dapat menunjang kegiatan sekolah dalam mendorong visi menjadi aksi. Karena akan sangat sulit dapat mengembangkan dan meningkatkan profesionalis-me kepala sekolah jika tidak ditunjangkan oleh sumber belajar yang memadai.

Selain itu kepala sekolah harus memiliki visi dan misi, serta strategi manajemen pendidikan secara utuh yang berorientasi kepada mutu. Strategi ini dikenal dengan manajemen mutu terpadu (MMT) atau kalau dunia bisnis dikenal dengan nama total quality management (TQM). Hal Yang merupakan usaha sistematis dan terkoordinasi untuk secara terus-menerus memperbaiki kualitas layanan.

Sedikitnya terdapat lima sifat layanan yang harus diwujudkan oleh kepala sekolah agar "pelanggan" puas; yakni layanan sesuai dengan yang dijanjikan (reliability), mampu menjamin kualitas pembelajaran (assurance), iklim sekolah yang kondusif (tangible), memberikan perhatian penuh kepada peserta didik (emphaty), dan cepat tanggap terhadap kebutuhan peserta didik (responsiveness).

Di tingkat pusat, program kerjasama untuk peningkatan mutu kepemimpinan kepala sekolah pun terus dilakukan. Salah satunya kerjasama dengan Temasek Foundation dan NIE dari Singapura. Sejumlah 120 kepala sekolah dan widyaiswara dari 30 provinsi di seluruh Indonesia berhak 
mengikuti Training of Trainer (TOT) di NIE Singapura selama 2 minggu sejak 23 Juni 2009. Mereka akan dilatih selama sepuluh hari untuk memaksimalkan potensi kepemimpinan dan manajerial dalam lingkungan sekolah. Anggaran yang disiapkan mencapai Rp 5,7 miliar yang sepenuhnya berasal dari Temasek Foundation. ${ }^{13}$

Berkaitan dengan soal solusi rekrutmen. Sejak otonomi daerah semua tergantung pada pemerintah daerah, termasuk kepala sekolah yang juga diangkat oleh bupati atau walikota. Seyogianya kepala sekolah yang dipilih diberi training agar belajar tentang manajemen kepala sekolah, supervisi, baru kemudian mendapat sertifikat kepala sekolah dan menjadi kepala sekolah. Saat ini, sistem pengangkatan kepala sekolah yang dilakukan pemda bervariasi. Ada pemda yang memilih untuk menyerahkan masalah tersebut kepada PMPTK agar memberi training lagi kepada calon kepala sekolah, namun ada pula bupati yang memilih untuk tidak memberi training lagi kepada si calon kepala sekolah.

Hal yang lebih berbahaya adalah apabila bupati yang mempunyai kewenangan untuk mengangkat kepala sekolah itu seenaknya saja memilih kepala sekolah karena kepala sekolah itu mendukung dirinya pada saat pilkada sedangkan kepala sekolah yang tidak mendukungnya tidak dipilih. Hal seperti ini ada yang terjadi, tandasnya. Untuk menghindari penyalahgunaan wewenang tersebut Surya Dharma mengimbau kepada para bupati ataupun walikota agar proses pemilihan kepala sekolah benar-benar dilakukan menurut standar kompetensi yang telah dibuat. Dia juga meminta para kepala daerah itu bersama-sama dengan pemerintah pusat bersama-sama menyediakan anggaran untuk pelatihan calon kepala sekolah.

Dengan mengetahui sumber kelemahan dari rekrutmen maka standar kompetensi untuk kepala sekolah harus betul-betul diimplementasikan dalam seleksi calon kepala sekolah dan pengawas. Kalau rekrutmennya sudah jelek maka dapatnya juga jelek, tegasnya. Pihaknya, dia menambahkan, saat ini sedang menyiapkan pedoman seleksi bagi calon kepala sekolah dan pengawas. Pedoman tersebut selanjutnya akan diusulkan untuk menjadi Permenpan. ${ }^{14}$

Tawaran lain dikemukakan oleh Trimo -dosen IKIP PGRI Semarang. Untuk meminimalisir kelemahan dalam rekrutmen kepala sekolah, dia mengajukan beberapa mekanisme sebagai solusi: Pertama, tahap perencanaan yang ditandai dengan penyiapan seperangkat aturan dan penilaian dalam proses rekrutmen, khususnya yang berkaitan dengan administrasi. Aturan tersebut hendaknya disebarluaskan dan hasil penilaian rekrutmen juga harus disampaikan secara transparan sehingga kepala sekolah yang 
diangkat benar-benar memenuhi aturan yang ditetapkan dengan perolehan nilai tertentu. Secara rinci, aturan tersebut meliputi: 1) masa kerja, tiap 1 tahun mendapat nilai 1, pangkat/golongan ruang (minimal III a dengan bobot nilai 20, selisih satu tingkat terpaut 5 nilai); 2) Basis pendidikan (minimal D II bobot nilai 40, S1 (75), S2 (110), dan S3 (150); 3) Prestasi guru/guru teladan/lomba kreativitas guru/ (tingkat Kec. Bobot nilai 15, Kab/Kota (25), Provinsi (75), dan Nasional (100); 4) Karya ilmiah/makalah/artikel/hasil penelitian/, tiap karya dihargai 5; 5) Keaktifan dalam organisasi profesi dan masyarakat, dengan bobot nilai 5 (Kec), 10 (Kab/Kota), 15 (Provinsi), 25 (Nasional); 6) Keikutsertaan dalam penataran, seminar dan sejenisnya, tiap sertifikat dihargai 2 (Kec), 5 (Kab/Kota), 5 (Provinsi), 10 (Nasional).

Kedua, tahap uji penguasaan kompetensi melalui tes tertulis dan wawancara yang mengacu pada pemahamam fungsi dan tugas kepala sekolah sebagai School Master dan Head Teacher. Tes tertulis perlu didesain dengan mengaktualisasikan domain kognitif, afektif dan psikomotor. Dengan demikian format yang cocok adalah tes uraian, bukan pilihan ganda.

Dengan mengacu pada aturan main tadi, seorang pendidik yang mencalonkan diri menjadi kepala sekolah harus berlomba-lomba meraih nilai tertinggi yang tidak dapat dimanipulasi. Hasil penilaian baik administrasi dan tes tertulis/wawancara pada akhirnya ditabulasi secara transparan, serta didistribusikan ke masing-masing sekolah. Paradigma ini, nantinya akan menepis anggapan bahwa pengangkatan kepala sekolah harus menggunakan "Vitamin D" sebagai uang pelicin.

Selebihnya, keberanian penyelenggara pendidikan untuk menerbitkan aturan mengenai pembatasan masa jabatan kepala sekolah sangat diharapkan agar seorang kepala sekolah yang diangkat dapat mengfungsikan dirinya sebagai School Master dan Head Teacher secara optimal dalam menumbuhkembangkan potensi dan prestasi sekolah yang dipimpinnya.

Akhirnya, profesionalisme kepala sekolah tidak hanya berpulang pada kepala sekolah itu sendiri, tapi juga dukungan, penghargaan dan political will pemerintah sangat dinantikan. Tanpa usaha serius dari semua pihak, kondisi guru dan kepala sekolah akan makin memprihatinkan dan profesionalisme sulit dicapai.

\section{SIMPULAN}

Kepala sekolah merupakan pemimpin formal yang tidak bisa diisi oleh orang-orang tanpa didasarkan atas pertimbangan tertentu. Untuk itu 
kepala sekolah bertangggung jawab melaksanakan fungsi-fungsi kepemimpinan baik yang berhubungan dengan pencapaian tujuan pendidikan maupun dalam menciptakan iklim sekolah yang kondusif yang menumbuhkan semangat tenaga pendidik maupun peserta didik. Dengan kepemimpinan kepala sekolah inilah, kepala sekolah diharapkan dapat memberikan dorongan serta memberikan kemudahan untuk kemajuan serta dapat memberikan inspirasi dalam proses pencapaian tujuan.

Kepala sekolah diangkat melalui prosedur serta persyaratan tertentu yang bertanggung jawab atas tercapainya tujuan pendidikan melalui upaya peningkatan profesionalisme tenaga kependidikan yang mengimplikasikan meningkatnya prestasi belajar peserta didik. Kepala sekolah yang profesional akan berpikir untuk membuat perubahan tidak lagi berpikir bagaimana suatu perubahan sebagaimana adanya sehingga tidak terlindas oleh perubahan tersebut.

Peningkatan profesionalisme kepala sekolah perlu dilaksanakan secara berkeinambungan dan terencana dengan melihat permasalahan-permasalahan dan keterbatasan yang ada. Sebab kepala sekolah merupakan pemimpin pendidikan yang juga bertanggung jawab dalam meningkatkan profesionalisme tenaga kependidikan lainnya. Kepala sekolah yang profesional akan mengetahui kebutuhan dunia pendidikan, dengan begitu kepala sekolah akan melakukan penyesuaian-penyesuaian agar pendidikan berkembang dan maju sesuai dengan kebutuhan pembangunan serta kemajuan ilmu pengetahuan dan teknologi. Akhirnya, Untuk mewujudkan kepala sekolah yang profesional tidak semudah membalikkan telapak tangan, semua itu butuh proses yang panjang.

\section{CATATAN AKHIR}

1. Sergiovanni, Supervision Human Perspectives, New York: McGraw Hill Book Company, 1987.

2. Syaiful Sagala, Kemampuan Profesional Guru dan Tenaga Kependidikan, Bandung: Alfabeta, 2009.

3. Ibid.

4. Pernyataan di atas dikemukakan oleh Surya Dharma saat jumpa pers mengenai forum kepala sekolah se-Asia Tenggara dan pemilihan kepala sekolah berprestasi, di Jakarta. Untuk sampai pada kesimpulan tersebut pihaknya mengembangkan semacam tes kompetensi terhadap 400 kepala sekolah di lima provinsi. Diakses di internet pada tanggal 3 Februari 2010.

5. Sebagaimana dilaporkan oleh wartawan Kompas, Siwi Nurbiajanti.

6. Sebagaimana dilaporkan di harian Pedoman Rakyat pada tanggal 20 November 2004, diakses di internet pada tanggal 29 Januari 2009. 
7. Dalam UU No 14 tahun 2005 tentang guru dan dosen dikatakan bahwa profesional adalah pekerjaan atau kegiatan yang dilakukan oleh seseorang dan menjadi sumber penghasilan kehidupan yang memerlukan keahlian, kemahiran atau kecakapan yang memenuhi standar mutu atau norma tertentu serta memerlukan pendidikan profesi.

8. Dilaporkan di harian Kompas, 12 September 2001, diakses di internet pada tanggal 29 Januari 2009.

9. Sebagaimana dilaporkan di harian Kompas, 15 Februari 2003, diakses pada tanggal 29 Januari 2009.

10. Trimo, Vitamin "D" dalam Pengangkatan Kepala Sekolah, Masihkah?. (http: //jamisten.wordpress.com/2008/02/27 Pengembangan Profesionalisme-kepala-sekolah.

11. Ibid.

12. Syaiful Sagala, Kemampuan Profesional Guru dan Tenaga Kependidikan, Bandung: Alfabeta, 2009.

13. Pernyataan ini dikemukakan oleh Direktur Tenaga Kependidikan Direktorat Jenderal Peningkatan Mutu Pendidik dan Tenaga Kependidikan (PMPTK) Depdiknas, Surya Dharma, diakses pada tanggal 1 Februari 2010.

14. Pernyataan di atas dikemukakan oleh Surya Dharma saat jumpa pers mengenai forum kepala sekolah se-Asia Tenggara dan pemilihan kepala sekolah berprestasi, di Jakarta.

\section{DAFTAR PUSTAKA}

Danim, Sudarwan, Inovasi Pendidikan dalam Upaya Peningkatan Profesionalisme Tenaga Kependidikan, Bandung: CV Pustaka Setia, 2002.

Harian Kompas, diakses tanggal 29 Januari 2010.

Harian Pedoman Rakyat, diakses tanggal 29 Januari 2010.

Harian Umum Pelita, Edisi 3 Februari 2010.

Indarafachrudi, Soekarto, Bagaimana Memimpin Sekolah yang Efektif, Bogor: Ghalia Indonesia, 2006.

Mulyasa, E., Menjadi Kepala Sekolah Profesional, Bandung: PT Remaja Rosdakarya, 2006.

Rahman, et. al., Peran Strategis Kepala Sekolah dalam Meningkatkan Mutu Pendidikan, Jatinangor: Alqaprint, 2006.

Sagala, Syaiful, Kemampuan Profesional Guru dan Tenaga Kependidikan, Bandung: Alfabeta, 2009.

Sergiovanni, Supervision Human Perspectives, New York: McGraw Hill Book Company, 1987.

Surya, Muhammad, Organisasi Profesi, Kode Etik dan Dewan Kehormatan Guru.

Trimo, "Vitamin D" dalam Pengangkatan Kepala Sekolah, Masihkah?, http://jamisten wordpress.com/2008/02/27 Pengembangan Profesionalisme-kepala-sekolah.

UU No. 14 tahun 2005.

Wahjosumidjo, Kepemimpinan Kepala Sekolah, Jakarta: PT Raja Grafindo Persada, 2002. 